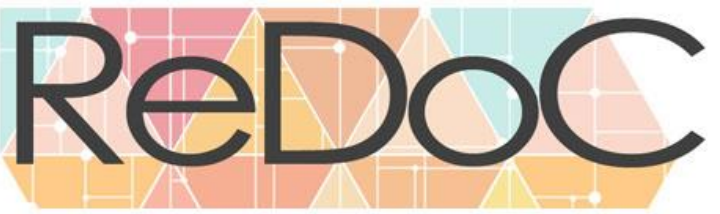

Revista Docência e Cibercultura

\title{
CORPOARTE E IDENTIDADES: UM ESTUDO SOBRE AS VISUALIDADES JUVENIS NAS ESCOLAS
}

\author{
ARTBODY AND IDENTITIES: A STUDY ABOUT YOUNG VISUALITIES AT \\ ASCHOOLS
}

\section{CUERPOARTE E IDENTIDADES: UN ESTUDIO SOBRE LAS VISUALIDADES JUVENILES EN LAS ESCUELAS}

Resumo: O objetivo da presente pesquisa consiste em investigar aspectos presentes nas apresentações corpóreas de alguns alunos de uma unidade do Colégio Pedro II, com idade entre nove e onze anos. As investigações acerca do tema foram realizadas a partir do seguinte problema: as imagens que os estudantes formulam com suas configurações corpóreas podem ser encaradas como um tipo de criação artística? Nesta reflexão, proponho também, demonstrar que a nossa experiência corporal, que cremos muitas vezes ser individual, está invadida e modelada, desde o início, pela sociedade em que vivemos e por nossas relações. Almejo, desta forma, apontar outras possibilidades de apreensão de um corpo frequentemente entendido como uma realidade cerrada e íntima e sublinhar a sua condição aberta e dinâmica em função da sua mediação social, e assim problematizar estéticas difundidas pelas mídias - que visam caracterizar as etapas da juventude analisar o papel reservado ao corpo dos estudantes no cotidiano escolar e realizar uma breve análise a respeito de sua participação no processo formativo. Proponho uma discussão acerca das imagens que os jovens figuram com seus corpos a fim de alinhavar outros contornos de nossas referências para o ensino e para nossa visão sobre o humano. Nos capítulos que integrarão esta pesquisa, abordarei o corpo como lugar de criação, real e potencial, como sujeito e objeto de suas próprias construções visuais, destacando também alguns aspectos do seu caráter simbólico.

Palavras-chave: Cotidiano Escolar. Arte. Corpo. Identidades. Juventudes

Abstract: The objective of the present research is to investigate aspects present in the bodily presentations of some students of a unit of the Pedro II College, aged between nine and eleven years. The investigations on the subject were made from the following problem: the images that the students formulate with their corporal configurations can be seen as a type of artistic creation? In this reflection, I also propose to demonstrate that our

Submetido em: 21/04/2018 - Aceito em: 30/04/2018 - Publicado em: 30/06/2018.

\footnotetext{
${ }^{1}$ Mestra em Educação pela Universidade Federal Rural do Rio de Janeiro e Professora de Artes e História
} da Arte em instituições privadas de ensino. E-mail: rosana.rmattos@gmail.com 


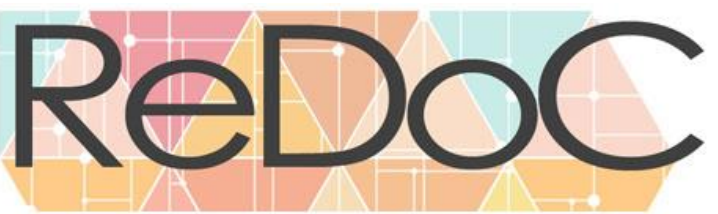

Revista Docência e Cibercultura

bodily experience, which we often believe to be individual, is invaded and shaped, from the beginning, by the society in which we live and by our relationships. Almejo, in this way, points out other possibilities of apprehending a body often understood as a closed and intimate reality and to underline its open and dynamic condition in function of its social mediation, and thus to problematize aesthetics diffused by the media - that aim to characterize the stages of youth - analyze the role reserved to the students' body in the daily school life and make a brief analysis regarding their participation in the formative process. I propose a discussion about the images that young people have with their bodies in order to align other contours of our references to teaching and our view of the human. In the chapters that will integrate this research, I will approach the body as a place of creation, real and potential, as subject and object of its own visual constructions, also highlighting some aspects of its symbolic character.

Key-words: Everyday School. Art. Body. Identities. Youth

Resumén: El objetivo de la presente investigación consiste en investigar aspectos presentes en las presentaciones corpóreas de algunos alumnos de una unidad del Colegio Pedro II, con edad de entre nueve y once años. Las investigaciones sobre el tema fueron realizadas a partir del siguiente problema: ¿Las imágenes que los estudiantes formulan con sus configuraciones corpóreas pueden ser encaradas como un tipo de creación artística? En esta reflexión, propongo también, demostrar que nuestra existencia corporal, que creemos muchas veces ser individual, está invadida y modelada, desde el inicio, por la sociedad en que vivimos por nuestras relaciones. Busco, de esta forma, apuntar otras posibilidades de presentación de un cuerpo frecuentemente entendido como una realidad cerrada e íntima y subrayar su condición abierta y dinámica en función de su mediación social, y así, problematizar estéticas difundidas por los medios - que buscan caracterizar las etapas de la juventud- analizar el papel reservado al cuerpo de los estudiantes en el cotidiano escolar y realizar un breve análisis sobre su participación en el proceso formativo. Propongo una discusión sobre las imágenes que los jóvenes figuran con sus cuerpos para entender otros contornos de nuestras referencias para la enseñanza y para nuestra visión sobre lo humano. En los capítulos que integrarán esta investigación, abordaré el cuerpo como un lugar de creación, real y potencial, como sujeto y objeto de sus propias construcciones visuales, destacando también algunos aspectos de su carácter simbólico.

Palabras clave: Cotidiano Escolar. Art. Cuerpo. Identidades. Jóvenes

\section{REFRÊNCIAS}

PINTO, Rosana da Silva, 1984 - Corpoarte e identidades: um estudo sobre as visualidades juvenis nas escolas. 2016. 